\title{
FILM ANIMASI SEBAGAI MEDIA PEMBELAJARAN TERPADU UNTUK MEMACU KEAKSARAAN MULTIBAHASA PADA SISWA SEKOLAH DASAR
}

\author{
Irfai Fathurohman, Agung Dwi Nurcahyo, Wawan Shokib Rondli \\ Prodi Pendidikan Guru Sekolah Dasar \\ FKIP Universitas Muria Kudus
}

\begin{abstract}
ABSTRAK
Film animasi merupakan salah satu media pembelajaran yang dapat digunakan untuk menjembatani pembelajaran agar lebih menarik dan memberikan nuansa lingkungan yang baru bagi siswa. Pentingnya media hadir dalam pembelajaran merupakan alternatif untuk memunculkan rangsangan, keaktifan, keterampilan yang baru bagi siswa dan mengetahui bentuk nyata terhadap aplikasi pembelajaran.

Penelitian ini menggunakan jenis penelitian kualitatif dengan tipe pemaparan deskriptif. Subyek pada penelitian ini merupakan siswa sekolah dasar yang ada di Kecamatan Dawe Kabupaten Kudus. Pengumpulan data menggunakan simak catat, teknik pustaka, observasi, dan wawancara. Teknik pemeriksaan keabsahan data menggunakan trianggulasi teori.

Hasil penelitian ini menunjukkan penggunaan film animasi dapat digunakan sebagai media pembelajaran tematik terpadu pada siswa sekolah dasar. Kedua, pembelajaran tematik terpadu dapat diaplikasikan dengan film animasi yang didalamnya menceritakan mengenai tema pembelajaran yang dipelajari siswa. Ketiga, kemampuan keaksaraan siswa dapat meningkat melalui penggunaan film animasi dengan multibahasa sebagai sarana pengenalan bahasa kepada siswa sekolah dasar.
\end{abstract}

Kata Kunci: Film Animasi, Media, Pembelajaran, Terpadu, Keaksaraan, Multibahasa.

\section{PENDAHULUAN}

Media merupakan salah satu penunjang pembelajaran yang perannya dalam kurikulum 2013 sudah menjadi sarana yang penting dalam setiap pembelajaran. Fungsi media menjadi penting manakala setiap pembelajaran berlangsung membutuhkan aplikasi teori yang dapat diketahui secara mudah dan tidak mengeluarkan banyak biaya. Hal itu merupakan kelebihan media ketika dipergunakan dalam pembelajaran.

Sumber belajar utama yang dapat digunakan dalam pembelajaran terpadu dapat berbentuk teks tertulis seperti buku, majalah, brosur, surat kabar, poster dan informasi lepas, atau berupa lingkungan sekitar, seperti lingkungan alam, lingkungan sosial sehari-hari. Seorang guru yang akan menyusun materi perlu mengumpulkan dan mempersiapkan bahan kepustakaan atau rujukan (buku dan pedoman yang berkaitan dan sesuai) untuk menyusun dan mengembangkan silabus. Pencarian informasi ini, sebenarnya dapat pula memanfaatkan perangkat teknologi informasi mutakhir seperti multimedia dan internet. Aktivitas peserta didik dalam penugasan dapat menjadi nilai tambah yang menguntungkan. (Trianto, 2010: 121)

Melalui pembelajaran tematik di sekolah dasar diharapkan agar siswa dapat belajar bermakna (learning by going). Anak dapat belajar dari pengalaman dalam lingkungannya, dengan adanya pengalaman ini anak dapat menkonstruksi 
pengetahuannya sendiri, sehingga pengetahuan yang dimiliki akan tersimpan dan akan mudah diingat oleh anak. Hal ini tentu sesuai dengan karakteristik anak usia kelas SD, yang masih berada pada tahap operasional konkrit dan anak memiliki kemampuan pada aspek kognitif, afektif, dan psikomotor (Yuliana dkk, 2014: 15).

Pembelajaran terpadu yang lebih menitik beratkan pada perluasan tema pada pembelajaran di sekolah dasar memerlukan keahlian dan keterampilan guru dalam memadukan setiap aktivitas pembelajaran menjadi lebih bervariatif tidak membosankan dan dapat dimaknai dengan baik ketika pembelajaran berakhir. Ketuntasan dan kesinambungan tema yang dipilih perlu direncanakan sebaik mungkin agar nantinya materi yang diberikan dapat terselesaikan sesuai dengan alokasi waktu.

Proses pembelajaran bersifat kompleks yang terdiri dari banyak bagian dan fungsi yang saling berhubungan, antara satu dengan yang lain harus saling berhubungan dan saling bekerja sama dalam cara yang terpadu agar tujuan dapat tercapai. Agar dapat menghubungkan semua komponen proses pembelajaran secara terpadu dalam rangka menghasilkan suatu program pembelajaran yang berhasil, dapat digunakan suatu pendekatan yang banyak dipakai yaitu pendekatan sistem. (Sunarti, 2013: 91).

Film animasi merupakan media yang menggabungkan antara audio dan visual dengan penceritaan cerita menggunakan langkah animasi atau seringpula disebut dengan kartun. Penggunaan film animasi dalam pembelajaran terpadu merupakan langkah untuk memberikan kemudahan bagi guru dalam mengaplikasikan materi pembelajaran sesuai dengan peran dan fungsinya.

Ketertarikan siswa terhadap film animasi perlu ditunjang pula dengan memberikan pengembangan aksara. Kesulitan siswa terhadap penguasaan dan pemahaman aksara perlu diantisipasi dengan pemberian cerita dalam film animasi yang didalamnya diceritakan dengan menggunakan aneka bahasa dalam berkomunikasi. Langkah tersebut dirasa akan mampu memberikan gambaran baik tulisannya maupun cara pengucapannya.

Seseorang dalam mempelajari bahasa, tentu mengharapkan manfaat yang dapat dipetik. Manfaat penguasaan berbahasa dapat diturunkan dari fungsi bahasa. Dari berbagai fungsi bahasa dapat diketahui dan dapat dipahami manfaat penguasaan berbahasa. Manfaat penguasaan berbahasa ialah mencakupi manfaat bagi penutur dan pendengar (Kanzunnudin, 2013: 25).

Bahasa adalah alat komunikasi yang digunakan manusia dengan sesama anggota masyarakat lain pemakai bahasa itu. Bahasa berisi gagasan, ide, pikiran, keinginan, atau perasaan yang ada pada diri si pembicara. Agar apa yang dipikirkan, diinginkan, atau dirasakannya dapat diterima oleh pendengar atau orang yang diajak bicara, hendaklah bahasa yang digunakannya dapat mendukung maksud atau pikiran dan perasaan pembicara secara jelas (Putrayasa, 2007: 1).

Berdasarkan pemaparan tersebut maka dalam penelitian ini dilakukan penelitian mengenai "Film Animasi sebagai Media Pembelajaran Terpadu untuk Memacu Keaksaraan Multibahasa pada Siswa Sekolah Dasar". Penelitian ini menfokuskan pada kriteria film animasi yang dapat digunakan sebagai media pembelajaran terpadu di sekolah dasar. Kedua, melalui penelitian ini film animasi dapat menjadi media pembelajaran terpadu di sekolah dasar, dan ketiga dapat memacu keaksaraan siswa dengan memanfaatkan film animasi. METODE

Penelitian ini menggunakan jenis 
penelitian kualitatif deskriptif, dimana pelaksanaannya dengan mendeskripsikan secara rinci dan jelas suatu kasus pembelajaran terpadu multibahasa yang didukung oleh media film animasi. Penelitian ini dilaksanakan di kecamatan Dawe Kabupaten Kudus dengan penerapannya pada tiga sekolah dasar yakni di SD 7 Cendono, SD 3 Kandangmas, dan SD 7 Kandangmas. Langkah penelitian yakni studi lapangan, studi literatur, media penunjang. Pengumpulan data dalam penelitian ini menggunakan simak catat, teknik pustaka, observasi, dan wawancara. Teknik pemeriksaan keabsahan data menggunakan trianggulasi teori yaitu peneliti dengan menggunakan perspektif lebih dari satu teori dalam membahas permasalahan yang dikaji. Proses analisis dalam penelitian kualitatif, secara khusus kegiatannya dilakukan secara induktif, interaksi dari setiap unit datanya, bersamaan dengan proses pelaksanaan pengumpulan data, dan dengan proses siklus (Sutopo, 2006: 116-117).

\section{HASIL}

Film animasi dapat digunakan dalam pembelajaran terpadu jika cerita yang diberikan sesuai dengan tema yang dipelajari saat itu. Film animasi dapat diaplikasikan dengan berbagai macam bahasa untuk menunjang keaksaraan siswa dengan langkah penerapannya yakni dalam kalimat perintah, kalimat tanya, petunjuk teknis, dan hal-hal yang umum yang menjadi kesenangan siswa selama ini. Kemampuan berbahasa siswa mulai dari bahasa Indonesia, bahasa Daerah, bahasa Inggris, dan bahasa penunjang yakni bahasa Korea dapat diajarkan dengan baik melalui media film animasi. Hal ini dibuktikan dengan ketertarikan siswa untuk mengikuti cerita film animasi, dan mempraktikkannya dengan baik petunjuk teknis, kalimat tanya, dan kalimat perintah yang selama ini sering disimak siswa untuk pembelajaran.

\section{PEMBAHASAN}

\section{Kriteria Film Animasi yang dapat digunakan sebagai Media Pembelajaran Terpadu di Sekolah Dasar}

Teks naskah (cerita) yang disusun untuk membuat film animasi merupakan cerita yang telah terkait dengan pembelajaran terpadu di sekolah dasar. Ketentuan mengenai kriteria film animasi yang dapat digunakan sebagai media pembelajaran terpadu di sekolah dasar adalah sebagai berikut:

a) Dapat ditangkap oleh penalaran siswa

Film animasi yang baik untuk diberikan ke siswa yakni sederhana, namun memiliki daya imajinasi yang positif kepada siswa. Faktor kesederhanaan cerita yang sesuai dengan kondisi siswa lebih membuat siswa tertarik dan mudah diingat siswa, karena hal-hal tersebut sering dialami siswa. Film animasi pada penelitian ini menggunakan cerita yang terjadi dalam kehidupan siswa sehari-hari dan dimungkinkan dapat terjadi pada kehidupan siswa.

b) Tidak terlalu panjang dan efektif dalam bercerita

Film animasi yang dikisahkan sebaiknya tidak terlalu panjang karena akan menghabiskan waktu pembelajaran. Perlunya menyiapkan film animasi yang sesuai dengan rencana pembelajaran dapat membantu guru dalam mengaplikasikan materi yang dipelajarinya saat itu. Pada penelitian ini peneliti memberikan batas waktu penayangan film animasi untuk mengatur perhatian, memacu keaktifan, dan memberikan waktu kepada siswa untuk merespons cerita yang telah ditayangkan.

c) Menggunakan bahasa yang santun.

Bahasa yang santun dan sesuai situasi kondisi penutur maupun mitratutur merupakan langkah yang dapat 
diaplikasikan kepada siswa untuk memberi pemahaman tentang peran bahasa sebagai sarana komunikasi. Pada penelitian ini peneliti menggunakan bahasa daerah ketika terjadi percakapan dengan sesama siswa, dan menambah bahasa Indonesia, bahasa Inggris ketika proses pembelajaran baik di kelas maupun di luar kelas, serta menambah bahasa Korea sebagai bahasa penunjang.

d) Berisi permainan yang menghibur dan tidak membahayakan siswa

Permainan merupakan langkah untuk meningkatkan daya pikir dan keterampilan siswa dalam menyelesaikan permasalahan yang ada. Film animasi pada penelitian ini mengaplikasikan permainan tradisional yang dapat meningkatkan kemampuan siswa dalam berpikir, dan mengatur strategi dalam setiap gerakannya. Namun yang terpenting dalam permainan ini yakni tidak membahayakan siswa, artinya permainan yang dimunculkan tidak membuat siswa semakin pasif saja namun diutamakan dapat aktif dan berperan langsung dalam permainan tersebut.

e) Berisi nilai-nilai yang dapat diketahui siswa.

Film animasi yang baik yakni didalam penceritaannya dapat menumbuhkan nilainilai positif dan dapat meningkatkan kecintaan siswa terhadap agamanya dan bangsanya sendiri. Rasa cinta terhadap tanah air dan mampu memahami kearifan lokal yang dimiliki oleh daerahnya masingmasing merupakan salahsatu faktor yang dapat dimunculkan pada film animasi. Pada penelitian ini peneliti mempergunakan.

Nilai-nilai kepedulian terhadap sesama, cinta tanah air, bekerja sama, toleransi antar umat beragama, saling menghargai, dan disiplin.

\section{Film Animasi Sebagai Media Pembelajaran Terpadu di Sekolah Dasar}

Penerapan film animasi pada penelitian ini dilakukan di sekolah dasar kecamatan Dawe Kabupaten Kudus. Untuk mengetahui peran film animasi dalam pembelajaran, maka peneliti menganalisis kebutuhan yang ada di lapangan terkait dengan wujud film animasi yang efektif dipergunakan di sekolah dasar. Adapun film animasi yang dianggap efektif untuk diberikan kepada siswa yakni yang benarbenar sesuai dengan materi pelajaran yang saat itu diajarkan kepada siswa, artinya tema yang digunakan untuk pembelajaran dapat terwakili dengan munculnya media film animasi, bukan sebaliknya film animasi yang ada justru bertolakbelakang dengan materi yang dipelajari.

Peran film animasi dalam pembelajaran merupakan pendukung yang dapat digunakan sewaktu-waktu oleh guru, dan bukan sebagai sarana yang terusmenerus dipergunakan dalam pembelajaran. Sumber utama pembelajaran tetaplah guru sebagai faktor penting yang tidak tergantikan. Dalam penelitian ini film animasi yang digunakan dalam pembelajaran yakni berisi tema kepedulian kepada sesama. Tema ini ditentukan atas dasar keadaan lingkungan di sekolah dasar agar nantinya siswa saling perduli terhadap keadaan orang lain sehingga muncul sikap sosial dan mau membantu orang lain yang sedang mengalami masalah.

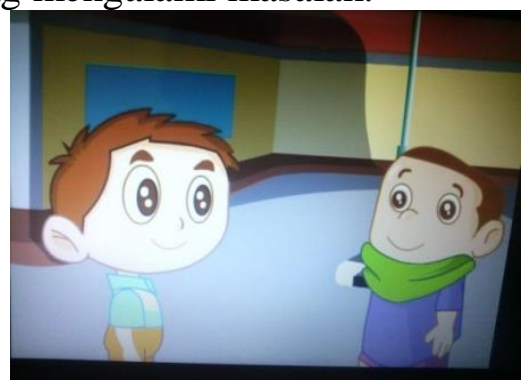

Gambar 1. Foto salah satu aktivitas tokoh dalam film animasi.

Melalui penceritaan dalam bentuk film animasi siswa mengalami kepekaan 
yang positif dengan memberikan respons dan aktif mengikuti pembelajaran. Hal ini disebabkan karena siswa melihat dan mengamati secara langsung peristiwa melalui film animasi.

\section{Langkah Memacu Keaksaraan Siswa dengan Memanfaatkan Film Animasi}

Pengenalan bahasa dapat dilakukan melalui berbagai cara dan bahasa bukanlah komunikasi yang dianggap sulit jika diberikan dalam situasi dan kondisi yang menyenangkan dan tidak menekan siswa untuk menghafal seperti apapun yang diberikan guru. Melalui film animasi diharapkan siswa dapat mengerti dan memahami peran berbagai bahasa dalam menunjang kemampuan daya serapnya terhadap kosakata asing yang belum dipahaminya.

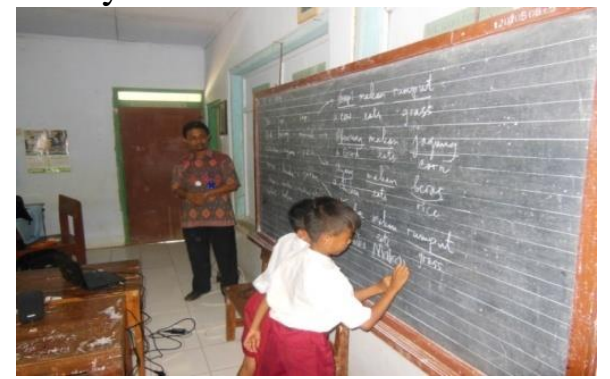

Gambar 2. Foto mengenai aktivitas siswa memberikan penjelasan mengenai keaksaraan dalam berbagai bahasa di SD 7 Kandangmas Dawe Kudus.

Pada gambar 2 tersebut siswa merespons pembelajaran terpadu dengan penggunaan multibahasa sebagai langkah meningkatkan kemampuan keaksaraan. Siswa dapat menjawab dan memberikan penjelasan mengenai penggunaan bahasa mulai dari bahasa Jawa, bahasa Indonesia, bahasa Inggris terkait dengan keadaan di sekitar siswa. Kemampuan ini menunjukkan bahwa siswa sekolah dasar di SD 7 Kandangmas Dawe Kudus memiliki kemampuan yang baik tentang keaksaraan berbahasa.

Berdasarkan penelitian tersebut maka ditambah bahasa penunjang ketika peneliti melakukan penelitian yang kedua kali. Bahasa penunjang yang diterapkan yakni dengan bahasa Korea. Pemilihan bahasa penunjang ini disebabkan fenomena yang terjadi di lapangan bahwa siswa sering menyanyikan dan menirukan alunan lirik lagu bahasa Korea namun belum memiliki kejelasan baik pengucapan dan pengenalan kosakatanya. Berdasarkan temuan tersebut pada penelitian ini ketika peneliti memberikan pembelajaran melalui film animasi dengan aplikasi bahasa penunjang yakni bahasa Korea siswa berantusias untuk mengikuti dan memahami pengucapan dan kosakatanya. Minat inilah yang menjadikan siswa lebih mudah untuk belajar bahasa asing sehingga tidak ada perasaan tertekan dan takut salah dalam mencoba mengucapkan dan menuliskan dengan baik.

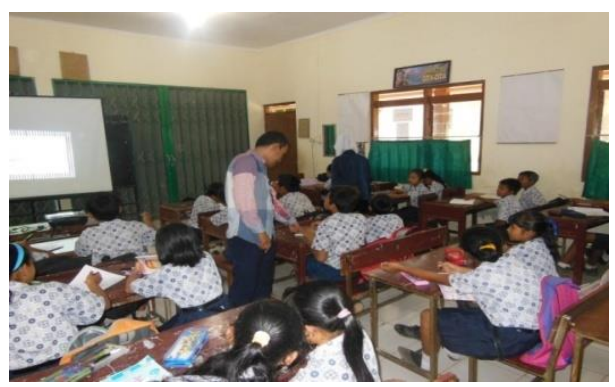

Gambar 3. Foto Pembelajaran dengan film animasi di SD 7 Cendono Dawe Kudus.

Pada penelitian di SD 7 Cendono Dawe Kudus, peneliti yang dibantu dengan mahasiswa memberikan langkah untuk meningkatkan keaksaraan siswa melalui bentuk permainan kata yang di dalam film animasi. Permainan ini diberikan untuk mengasah kemampuan siswa dalam merangkai kata-kata menjadi kalimat, dan dari kalimat menjadi suatu paragraf. Adapun kata-kata yang digunakan untuk permainan yakni kata-kata yang sering disimak siswa dalam kehidupan sehari-hari, seperti katakata yang mengandung perintah, ajakan, penyemangat, dan larangan.

Berdasarkan penelitian yang telah 
dilakukan peneliti menemukan hal yang positif dari penggunaan film animasi untuk meningkatkan keaksaraan siswa. Pertama, film animasi dapat digunakan dan dipilih serta diatur tempo dan kesempatan untuk menfokuskan perhatian siswa terhadap tayangan yang telah disaksikan siswa. Melalui pengaturan ini siswa akan belajar untuk menghargai setiap waktu, dapat terkendali dalam mengorganisasikan kelas, dan mampu berkompetisi untuk menjawab dan mengemukakan pemikiran yang telah diperoleh. Kedua, melalui film animasi yang berisi permainan maka siswa akan terasah kemampuannya untuk mengingat, berpikir, dan berkreasi dalam menyusun, merangkai, dan mengembangkan kata-kata sesuai dengan hasil pemikirannya.

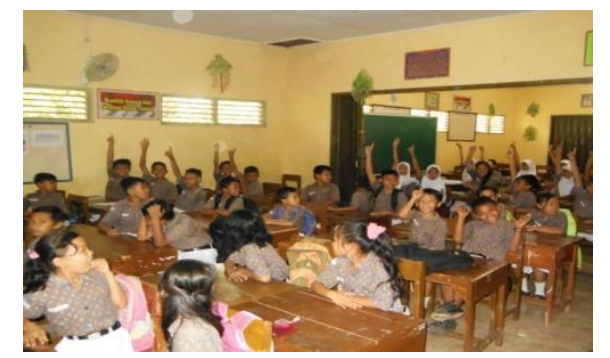

Gambar 4. Foto keaktifan siswa dalam menjawab keaksaraan di SD 3 Kandangmas Dawe Kudus.

Penelitian yang dilakukan oleh peneliti di SD 3 Kandangmas Dawe Kudus dengan mengaktifkan kemampuan siswa untuk menjawab pertanyaan yang ada dalam film animasi. Berdasarkan penelitian yang telah dilakukan siswa berantusias untuk menjawab pertanyaan yang diberikan melalui penanyangan film animasi. Keaksaraan siswa semakin meningkat ketika pembelajaran diberikan. Hal ini dibuktikan dengan jawaban yang diberikan siswa ketika dimunculkan pertanyaan-pertanyaan mengenai materi yang ada dalam film animasi dengan bahasa inggris siswa mampu menjawab maksud kalimat tanya yang diberikan dengan benar.

\section{SIMPULAN}

Media dalam pembelajaran menjadi salah satu alternatif untuk memacu keaktifan siswa, keterampilan, dan pengetahuan siswa saat mempelajari materi pembelajaran. Pembelajaran tematik terpadu di sekolah dasar dapat dimasukkan berbagai aneka bahasa sebagai langkah dalam mengenalkan keaksaraan kepada siswa agar nantinya siswa dapat mengerti tentang berbagai bahasa asing yang belum diketahuinya.

Aksara merupakan salah satu penentu dalam keberhasilan pendidikan. Semakin banyak siswa mengenal aksara baik bahasa Ibu, bahasa Kedua, dan bahasa ketiga maka dirinya akan mengenal berbagai peristiwa dan lingkungan di daerah lain agar kematangan, kepekaan, dan pengetahuannya semakin bertambah. Bagi siswa sekolah dasar mengenal aksara sejak dini akan memberikan kemudahan di jenjang berikutnya karena dirinya akan mengaplikasikan kemampuan yang telah dimilikinya dengan pengembangan yang lebih luas lagi tentang keaksaraan yang terkonsep dalam pemikirannya.

\section{SARAN}

Keterampilan guru dalam mengolah media pembelajaran semenarik dan tepat sasaran merupakan faktor penting dalam kesuksesan pembelajaran. Media film animasi yang sudah tergolong baik yakni yang dapat mewakili berbagai macam materi dan sesuai dengan pemahaman siswa di sekolah dasar. Hal ini pelru diketahui oleh guru, agar nantinya film animasi yang dipilih tidak asal dan memberikan pemahaman negative kepada siswa.

Pengenalan aksara penting untuk dikenalkan dan diajarkan kepada siswa sejak dini, hal ini disebabkan keaksaraan yang dimiliki siswa cenderung masih dalam kemampuan monolingual dan dwilingual. 
Minat dan kreativitas anak dalam mengetahui mengenai bahasa asing perlu didukung dengan langkah mengenalkan setiap saat kosakata bahasa asing yang disukai siswa agar nantinya siswa semakin senang belajar bahasa asing.

\section{DAFTAR PUSTAKA}

Trianto. 2010. Model Pembelajaran Terpadu Konsep, Strategi, dan Implementasinya dalam Kurikulum Tingkat Satuan Pendidikan (KTSP). Jakarta: PT Bumi Aksara.

Kanzunnudin Mohammad. 2013. Bahasa Indonesia untuk Perguruan Tinggi. Kudus: Yayasan Adhigama.

Putrayasa Ida Bagus. 2007. Kalimat Efektif (Diksi, Struktur, dan Logika). Bandung: PT Refika Aditama.

Sutopo, H.B. 2006. Metodologi Penelitian Kualitatif, Dasar Teori dan Terapannya dalam Penelitian. Surakarta: Universitas Sebelas Maret Press.

Sunarti. 2013. Pengembangan E-Learning Mata Kuliah Pendidikan Bahasa Indonesia Sekolah Dasar. Jurnal Pedagogik Pendidikan Dasar, Jilid 1, Nomor 1, Januari 2013, Hal. 90-103.Bandung: UPI.

Yuliana Pranita, Lusa Herman, Wurdjinem. 2014. Penerapan Pembelajaran Tematik dengan Mengunakan Metode Role Playing untuk Meningkakan Kualitas Pembelajaran Siswa Kelas III Sekolah Dasar 04 Kota Bengkulu. Jurnal Pedagogik Pendidikan Dasar, Jilid 2, Nomor 1, Januari 2014, Hal.13-28. Bandung: UPI. 